\title{
CVケーブル・接続部の高温運転機械特性
}

\begin{tabular}{|c|c|c|c|c|c|c|c|}
\hline 正 & 中出 & 雅彦 & (東京電力) & 正員 & 松井 & 俊哉 & (東京電力) \\
\hline 正 & 田中 & 秀郎 & （古河電工） & 正員 & 西川 & 哲 & (住友電工) \\
\hline E & 片貝 & 昭史 & (日立電線) & 正員 & 三宅 & 清市 & (昭和電線) \\
\hline & 森 & & (三菱電線) & & & & \\
\hline
\end{tabular}

\section{Mechanical Characteristics of an XLPE Cable and a Joint under High Temperature}

Masahiko Nakade, Member, Toshiya Matsui, Member, (Tokyo Electric Power Co.), Hideo Tanaka , Member (The Furukawa Electric Co., Ltd.), Satoshi Nishikawa, Member (Sumitomo Electric Industries, Ltd.), Shoshi Katakai, Member (Hitachi Cable, Ltd.), Seiichi Miyake, Member (Showa Electric Wire \& Cable Co., Ltd.), Koichi Mori, Member (Mitsubishi Cable Industries, Ltd.)

Characteristics of crosslinked polyethylene used in XLPE cable change much over $100{ }^{\circ} \mathrm{C}$. Mechanical characteristics of crosslinked polyethylene insulated cables and tape lapped joints under high temperature condition were studied. A cleat doesn't change shape of a cable and short-circuit current and ground fault current don't damage a cable at about $105^{\circ} \mathrm{C}$. On the other hand, at about $105^{\circ} \mathrm{C}$, performance of water impervious layer degraded. Copper taps lapped shield are broken at an offset position with thermal expansion and contraction. Support force of a cleat decreases and lead tape lapped shield is broken.

$$
\text { キーワード:CVケーブル、接続部、高温熱機械特性 }
$$

\section{1.はじめに}

CVクーブルの絶縁体として使用されている架橋ポリエチレ ン(XLPE) 仕、 $100^{\circ} \mathrm{C}$ 程度の温度以上で機械的な物性が 急激に変化し、それにつれて電気的な特性も変化する(1)。 一般的にはケーブルとして必要な電気性能、機械性能は低 下する。

本報告では、高温連転がケーブルおよび接続部に与える 影響を特に熱機械特性に着目し、それぞれについて初期性 能、もしくは、長期性能の検討を行った。

\section{CVケーブルの高温熱機械特性}

<2.1>CVケーブルの高温変形特性高温領域におけるC Vケーブルの加熱変形について検討する。
2.1.1 試験方法供試試料として 2 種の $66 \mathrm{kV} \mathrm{CVケーブル}$ を用いた。ここで、ケーブル絶縁体は、低密度ポリエチレン (LDPE) (密度: 約 $0.92 \mathrm{~g} / \mathrm{cm}^{3} 、 \mathrm{MI}$ : 約 1) 化学架橋さ せた(架橋度: 約 $80 \%$ ) のXLPEであり、ケーブルシースは、 沉用の軟質ビニルシースである。

(i) 新品 $66 \mathrm{kVCV}$ ケーブル(絶縁厚: $9 \mathrm{~mm}$ 、導体サイズ: $\left.200 \mathrm{~mm}^{2}\right)$ (銅口イヤー遮蔽、遮水層付きシース)

(ii) 経年 15 年撤去 $66 \mathrm{kVCV}$ ケーブル(絶縁厚: $11 \mathrm{~mm}$ 、 導体サイズ: $800 \mathrm{~mm}^{2}$ ) (銅テーブ遮蔽、遮水層なしシ 一ス)

これら試料を用いて、下記手法によりCVケーブルの加熱変 形を調查した。

（1）CVケーブルの加熱変形率の温度依存性 試料(i)のシ 一スを含さ輪切りサンプル（長さ $30 \mathrm{~mm}$ )を恒温槽に入れ、 30 分予熱、30分荷重 $(9 \mathrm{~kg}$ :ケーブル単位重量約 $4.5 \mathrm{~kg}$ の 倍)を加け変形率を測定。加熱温度 ( 7 種):60、90、105、 
120、140、160、180 $\mathrm{C}$ 。荷重をかけるにあたっては、加 熱変形器でケーブルの上下を平板ではさみ、所定の重量を がけた。

（2）長期課通電試酫後のCVケーブルの通常部、拘束部の 変形状況調查図1に示寸試験回路を組み立て、表1の上 うに課通電試験を実施した。No.3、No.4の雷Imp. 電圧 は、3回目ヒートサイクル終了時(導体温度がそれぞれ 12 $0^{\circ} \mathrm{C} 、 140^{\circ} \mathrm{C}$ のき)、印加している。試験終了後、ケーブル 部、拘束部(クリート部、管路口防水装置部)を解体し、変形 状況を調查した。なお、拘束の仕方はクリート部: 最大面圧 5 $\mathrm{kg} / \mathrm{cm}^{2}$ 以下でスプリングをかけ締め付け、管路口防水装 置部:ケーブルと管路口の隙間をゴムパッキンでふさぎ、防 水処理とした。表中の温度は導体温度。

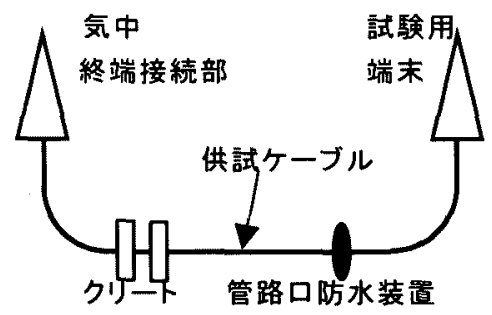

図 1 課通電試験状況

Fig.1 Configuration of long term test set up of XLPE cable with cleats and a water-tight duct plug

表 1 課通電試験手順

Table 1 Long term test procedure of XLPE cable with cleats and a water-tight duct plug

\begin{tabular}{|c|c|c|c|c|c|}
\hline \multirow[t]{2}{*}{ No. } & \multicolumn{5}{|c|}{ 課通電手順 } \\
\hline & $\begin{array}{c}\mathrm{AC} \\
105 \mathrm{kV} / \\
1 \mathrm{~h}\end{array}$ & $\begin{array}{c}\mathrm{AC} 42 \mathrm{kV} \\
/ 3000 \mathrm{~h}\end{array}$ & $\begin{array}{c}\mathrm{AC} \\
42 \mathrm{kV} \\
/ 6 \mathrm{~h}\end{array}$ & \begin{tabular}{|c|} 
雷 $\operatorname{Imp}$ \\
-350kV/ \\
3回
\end{tabular} & $\begin{array}{c}\mathrm{AC} \\
42 \mathrm{kV} \\
/ 168 \mathrm{~h}\end{array}$ \\
\hline 1 & 常温 & $\begin{array}{l}105^{\circ} \mathrm{C} \\
\text { 連続 }\end{array}$ & - & $105^{\circ} \mathrm{C}$ & \\
\hline 2 & 常温 & $\begin{array}{c}115^{\circ} \mathrm{C} \\
\text { 連続 }\end{array}$ & $\overline{-}$ & $115^{\circ} \mathrm{C}$ & $90^{\circ} \mathrm{C}$ 連続 \\
\hline 3 & 常温 & $\begin{array}{l}105^{\circ} \mathrm{C} \\
\text { 連続 }\end{array}$ & \multicolumn{2}{|c|}{$\begin{array}{l}105 \sim 120^{\circ} \mathrm{C} \\
\text { ヒートサイクル* }\end{array}$} & \\
\hline 4 & 常温 & $\begin{array}{l}105^{\circ} \mathrm{C} \\
\text { 連続 }\end{array}$ & \multicolumn{2}{|c|}{ 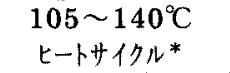 } & \\
\hline
\end{tabular}

*注)ヒートサイクル3回害施 (5hで昇温・1h保持)

\subsection{2 試酸結果}

（1）CVケーブルの加熱変形率の温度依存性 CVケーブ ルのシース込みでの加熱変形率((荷重前の厚さ一荷重後 の厚さ)／荷重前の厚さ×100)を図2に示す。CVケーブル の加熱変形率は、 $105^{\circ} \mathrm{C}$ 越えると変形度合は大きくなって ゆく。180 Cにおいてもその絶対值は $20 \%$ 程度と小さいが、 泠却後のケーブルの状況をみると、140ㄷで銅ワイヤーの

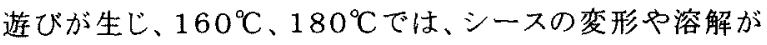
激しい状況であった。
（2）長期課通電試鍳後のCVケーブルの通常部、拘束部の 変形状況 表1に示した課電履歴において、ケーブルに絶 縁破壊が生ずることはなかった。しかし、通常部では、押さ

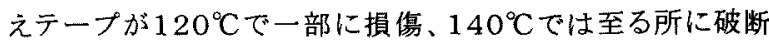
が認められた。また拘束部では、シースに $140^{\circ} \mathrm{C} て ゙$ 著しい変 形が認められ、その変形はケーブルコアにまで達していた。 図3にケーブル絶縁体の絶縁厚の変化(絶縁厚の最小值 測定: 変化率 $=(($ 試験後の絶縁厚さ一試験前の非拘束部の 絶縁厚さ)／(試験前の非拘束部の絶縁厚さ) $\times 100)$ を示 す。また、クリート部のコアの変形状況を図4に示す。

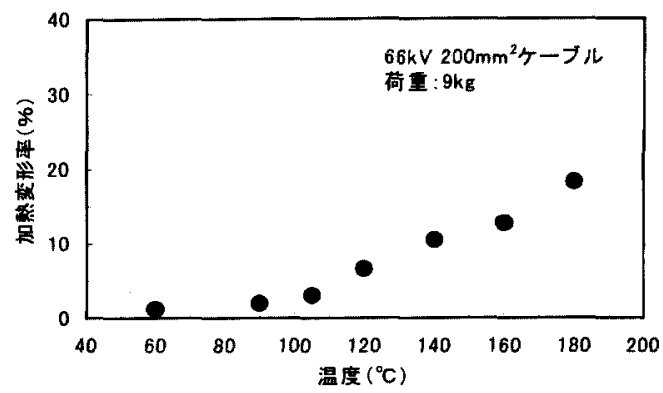

図2 CVクーブル(シース込み)の加熱変形率温度依存性

Fig. 2 Deformation of XLPE cables due to temperature rise

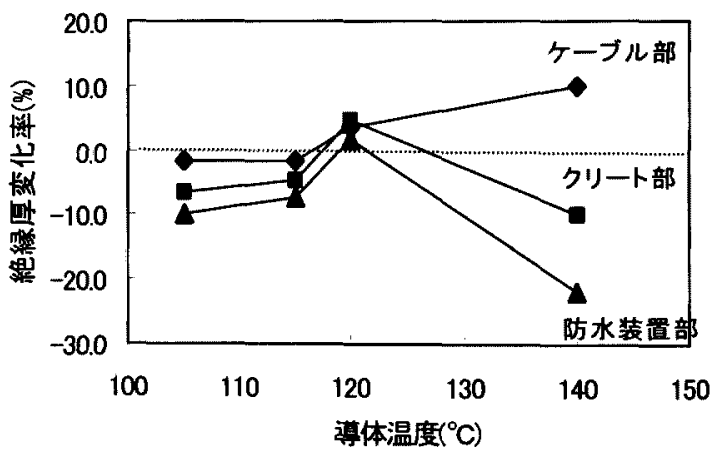

図3 CVケーブルの絶縁厚変化の温度依存性

Fig. 3 Deformation of insulation thickness of XLPE cables due to temperature rise

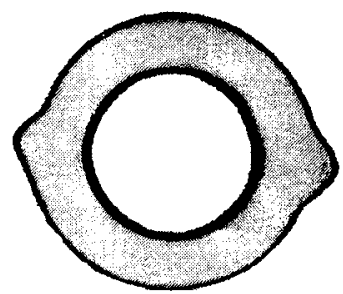

(a) $140^{\circ} \mathrm{C}$

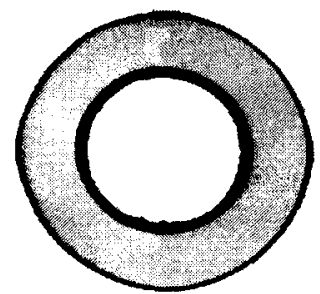

(b) $120^{\circ} \mathrm{C}$
図4 クリート拘束部のケーブルコア変形状況

Fig.4 Deformation of XLPE cable core created at high temperature. 
2.1.3 考察 今回の試験結果から、CVケーブルが高温にさ らされると大きな変形が生じることが明らかとなった。拘束部 では、120ㄷを越えるとただちに絶縁破壊は起こさないもの

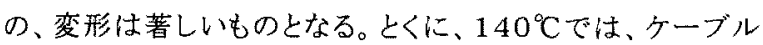
コアにまでその変形は達し、ケーブルの最小絶縁厚を割り 込むまでになっている。(図4，(a))このことから、CVケーブ ルの高温使用にあたっては、ケーブルの拘束部に対し、十 分に対処する必要のあることが分かる。

<2.2>遮水首の熱機械劣化特性 CVケーブルの主要な劣 化要因に外部からの水の浸入による水トリーの発生がある。 これを抑制、防止するためにはケーブルに遮水層を施すこ とが有効である。特に66 kVCVケーブルでは、鉛ラミネート テープをシース内面に接着させた簡易㵂水層が適用されて いる。

しかし、ケーブルが高温使用された場合には、設計以上の 機械的ひずみがかかり、その履歷による遮水層の劣化が奬 念される。そこで、高温使用時の熱伸雉による遮水層の劣 化特性を、大きなひずみの加わるオフセット部分に着目し検 討した。

2.2.1 遮水性能評価法遮水性能は以下の方法で評価し た。なお、透水性能評価試料は、2.2.2で武験が終了したケ ーブルに対し、図5に示卞 $\mathrm{A}$ 部、B〜C部の中閒、C D 部 の中間を採取し、ケーブル内部のコア及び遮蔽層を除去し たシースのみの状態にしたものを用いた。

(i)コアを取り除いた遮水層付きシース内に十分乾燥した シリカゲルを入れて、両端を融着密封する。

(ii)上記を $60^{\circ} \mathrm{C} の$ 温水中に30日間浸漬する。

(iii)封入したシリカゲルの重量增加を測定することで、透 湿した水分量 $Q(\mathrm{~g})$ がわかる。

(iv) 次式 (1)により、

透湿度 $P(\mathrm{~g} \cdot(\mathrm{cm} / \mathrm{cm} 2) /(\mathrm{day} \cdot \mathrm{mmHg}))$ 学計算する。

$$
P=\frac{Q / L \times \ln \left(R_{2} / R_{1}\right)}{2 \pi t d}
$$

ここで、 $R_{2}:$ シ一ス外径 $(\mathrm{cm}) 、 R_{1}$ :遮水層内经 $(\mathrm{cm}) 、$

$L$ :試料長 $(\mathrm{cm}) 、 t$ : 試験時間 $(\mathrm{day}) 、 d$ : 試験温度における飽和 蒸気圧 $(\mathrm{mmHg})$ である。

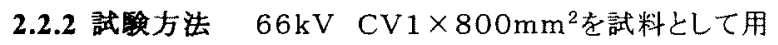
い、図5に示すような立体オフセットを構成し30年相当の熱 伸縮履歴を与えた。供試ケーブルの仕様等を表 2 に示す。

オフセット線形は管路長 $500 \mathrm{~m}$ における雨側伸び出しを 想定して、管路内導体温度 $90^{\circ} \mathrm{C}$ 時の伸び出しでケーブル が筝容曲げ半径である12Ds(ケーブル外径の12倍)となる ような等連接 2 円弧オフセット線形とした。 伸縮は等価 30 年の履歴として以下を与えた。 日間相当分伸び出し量 (1日の負荷変動を想定)

$24 \mathrm{~mm}$ (導体温度 $90^{\circ} \mathrm{C}$ 時) $\times 9150$ 回

$70 \mathrm{~mm}$ (同 $105^{\circ} \mathrm{C}$ 時 $) \times 1800$ 回
年間相当分伸び出し量 ( 1 年間の温度変化を想定 $)$ $265 \mathrm{~mm}$ (同 $105^{\circ} \mathrm{C}$ 時) $\times 30$ 回

また、実運転中のケーブルを想定し、40〜100 ${ }^{\circ} \mathrm{C}$ のヒート

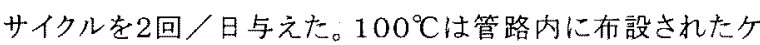
一ブルの導体温度が $105^{\circ} \mathrm{C}$ とる時のマンホール部のケー ブル導体温度にほぼ相当する。

表 2 供試ケーブルの主な仕様等

Table 2. Specification of sample cable.

\begin{tabular}{|c|c|c|c|}
\hline & & 項目 & 仕様 \\
\hline r & 導 & 公称断面積 $\left(\mathrm{mm}^{2}\right)$ & 800 (円形压縮) \\
\hline 1 & 体 & 外径 & 34.0 \\
\hline ブ & & 絶縁体厚さ (mm) & 10.0 \\
\hline ル & & 遮水層厚さ $(\mathrm{mm})$ & 0.3 \\
\hline 構 & & シース厚さ $(\mathrm{mm})$ & 4.0 \\
\hline 造 & & ケーブル外径 & 73.0 \\
\hline & & 絶縁体 密度 & 約 0.92 \\
\hline & & 絶縁体 架橋度 & 約 $83 \%$ \\
\hline 物卜 & & 絶縁体 MI & 約 1 \\
\hline & & 遮水金属層種類 & 鉛合金 \\
\hline & & 遮水金属層厚さ & $50 \mathrm{~mm}$ \\
\hline
\end{tabular}

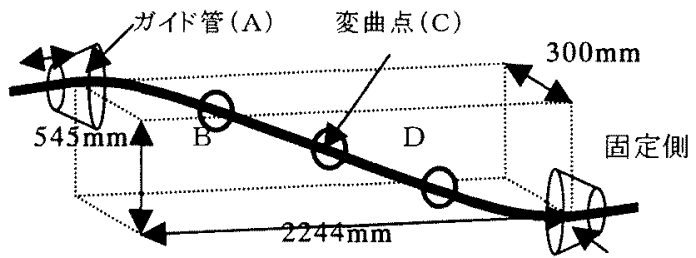

ガイド管(E)

図5 オフセッ線形

Fig.5 Layout of offset.

2.2.3 試聒結果 30 年相当のオフセット伸絤後に実施した 透湿度測定結果を表了に示す。これに合わせて供試試料の 初期透湿度测定結果を示した。このように、10 ${ }^{\circ} \mathrm{C}$ 相当の機 械履歴を 30 年分与えることにより、オフセット部の透湿度は 著しく低下寸ることが明らかになった。現状東京電力の 154 $\mathrm{kVCV}$ ケブルの規格值は $1.0 \times 10^{-7} \mathrm{~g} \cdot\left(\mathrm{cm} / \mathrm{cm}^{2}\right) /$ (day/mmHg) であり、これを割り込んでいる。また、各部 の解体調查索行った結果を表4に示す。透湿度の低下度に 伈じた劣化状況にあることがわかる。特に劣化の著しい箇所 は、設計上の変曲点(不動点)であるC部であった。

表 3 透湿度測定結果

\begin{tabular}{c|c} 
Table 3 Measured moisture permeability. \\
\hline 測定箇所 & $\begin{array}{c}\text { 透湿度 } \\
\mathrm{g} \cdot(\mathrm{cm} / \mathrm{cm} 2) /(\mathrm{day} . \\
\mathrm{mmHg})\end{array}$ \\
\hline 初期値 & $1.49 \times 10^{-9}$ \\
\hline $\mathrm{A}$ 部 & $4.14 \times 10^{-7}$ \\
\hline $\mathrm{B}$ 部 $\sim$ C部間 & $5.22 \times 10^{-7}$ \\
\hline $\mathrm{C}$ 部 $\sim \mathrm{D}$ 部間 & $4.03 \times 10^{-7}$ \\
\hline
\end{tabular}


表 4 遮水層解体調査結果

Table 4 Observation results of water impervious layer.

\begin{tabular}{|c|c|c|}
\hline 箇所 & 鉛遮水層の劣化状況 & $\begin{array}{c}\text { 劣化位置 } \\
\text { と程度 }\end{array}$ \\
\hline B & $\begin{array}{c}\text { 嚾かなしわあり(曲げ内側) } \\
\text { 僅かなへアクラックあり } \\
\text { (曲げ外側) } \\
\end{array}$ & \\
\hline $\mathrm{C}$ & $\begin{array}{c}\text { クラック(曲げ内側) } \\
\text { 及びへアクラックあり } \\
\text { (曲げの内外側) }\end{array}$ & \\
\hline D & $\begin{array}{l}\text { ヘアクラックあり } \\
\text { (曲げの内外側) }\end{array}$ & \\
\hline
\end{tabular}

2.2.4 考察 ケーブル導体温度 $105^{\circ} \mathrm{C}$ に相当する条件で試 験されたオフセット部遮水層には、著しい透湿度の低下並 びに遮水層の損傷が確諗された。これは設計以上の厳しい 機械履歴が繰り返し与えられたことによる鉛ラミネートテープ の疲労劣化である。設計上C部は不動点のはずであるが、 実際のケーブル举動は理論通りにはならずに、下に撓んだ ような変形を起こす ${ }^{(2)}$ 。このときC 部付近には786 mmと、許 容曲げ半径 $877 \mathrm{~mm}$ 以下の厳しい変形が起きており、これ が遮水層の劣化並びに透湿度の性能低下を引き起こしてい る。

このように、 $105^{\circ} \mathrm{C}$ 以の温度領域でのCVケーブルの運 用は、温度が高いことにより、伸び出し量が増え、これにより オフセット部が大きく変形し、遮水層にクラックを生じさせ、 遮水性能の低下をむたらす可能性がある。

<2.3> 金属遮做層の熱機械少化特性管路布設のマンホ 一ル部のオフセットを模擬した試料に、高温使用条件による 熱伸縮およびヒートサイクルを与え、オフセット部のケーブル 金属遮蔽層の疲労特性について检討を行った。

\subsection{1 試酸方法}

(1) 供試ケーブル

(a) $66 \mathrm{kV} \mathrm{CV} 1 \times 800 \mathrm{~mm}^{2}$ (銅テープ遮蔽層（遮蔽層は0. $2 \mathrm{~mm}$ 厚の軟銅テープを2枚を相互逆方向に重ね巻き)/経 年 19 年撤去品)

(b) $66 \mathrm{kV} \mathrm{CV} 1 \times 800 \mathrm{~mm}^{2}$ (ワイヤ一遮蔽層（遮蔽層は 1.2 $\mathrm{mm}$ 軟銅線 40 本を層心径の8倍以下でピッチ巻き)/新品）

(2) 試确条件

オフセット形状、伸縮量及びヒートサイクルは表5に示す条件 とした。伸縮量とヒートサイクルパターン例を図6に示す。伸縮 は機械的に与え、ヒートサイクルは通電電流により与えた。

2.3.2 試鉤結果 銅テーブ遮蔽層の試料(a)では、X線観察 により初期には認められなかった銅テープしわが伸縮 30 年 相当時 (X線観察間隔15、30、45 年相当) か吅認められ、45 年相当時には破断に至った。

一方、ワイヤー遮蔽層試料(b)-(1),(2)では、試験終了後の解 体調查でもワイヤーに異常は発生しなかった。ヒートサイクル 試験を課通電試験としたケースもあるが、残存性能試験でむ
まったく異常は認められなかった。

なお、オフセット試験中にオフセット形状の測定を実施した ところ、オフセット変形は2.2.4で述べたように理論通りには なっていない。

表 5 試験条件

Table 5 Test condition

\begin{tabular}{|c|c|c|c|c|}
\hline $\begin{array}{l}\text { 試 } \\
\text { 料 }\end{array}$ & オフセット形状 & 伸縮量 & $\begin{array}{l}\text { 伸縮 } \\
\text { 回数 }\end{array}$ & 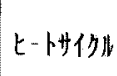 \\
\hline (a) & $\begin{array}{l}\text { 水平 } \\
\text { 長さ } 2050 \mathrm{~mm} \text { 幅 } 400 \mathrm{~mm} \\
220 \mathrm{~mm} \text { 伸び出し時に } \\
\text { ケ・ブ曲げ半径 } \mathrm{R}=10 \mathrm{Ds}\end{array}$ & $\begin{array}{l}\text { 年間: } 220 \mathrm{~mm} \\
\text { 日間: } 30 \mathrm{~mm}\end{array}$ & $\begin{array}{l}60 \text { 年 } \\
\text { 相当 }\end{array}$ & 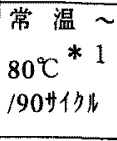 \\
\hline \multirow[t]{2}{*}{ (b) } & $\begin{array}{l}\text { (1)水平 } \\
\text { 長さ } 2050 \mathrm{~mm} \text { 幅 } 400 \mathrm{~mm} \\
220 \mathrm{~mm} \text { 伸び出し時に } \\
\text { ケープル曲げ半径 } \mathrm{R}=10 \mathrm{Ds}\end{array}$ & $\begin{array}{l}\text { 年間: } 220 \mathrm{~mm} \\
\text { 日間: } 30 \mathrm{~mm}\end{array}$ & $\begin{array}{l}\text { 60年 } \\
\text { 相当 }\end{array}$ & $\begin{array}{l}\text { 常温 } \\
105^{\circ} \mathrm{C} \\
160^{4} \text { 仯 }\end{array}$ \\
\hline & $\begin{array}{l}\text { (2)立体 } \\
\text { 長さ } 2180 \mathrm{~mm} \text { 幅 } 300 \mathrm{~mm} \\
\text { 高さ } 545 \mathrm{~mm} \\
230 \mathrm{~mm} \text { 伸び出し時に高 } \\
\text { さ } 545 \mathrm{~mm} \text { ケープ施曲げ半径 } \\
\text { R=12Ds }\end{array}$ & $\begin{array}{c}\text { 年間 : } 230 \mathrm{~mm} \\
\text { 日間: } 70 \mathrm{~mm} \\
\left(105^{\circ} \mathrm{C} \text { 時 }\right) \\
24 \mathrm{~mm} \\
\left(90^{\circ} \mathrm{C} \text { 時 }\right)\end{array}$ & \begin{tabular}{|l|}
30 年 \\
相当
\end{tabular} & $\begin{array}{l}\text { 常温 } \\
95^{\circ} \mathrm{C}^{* 2} \\
130^{+1} \text { 仂 }\end{array}$ \\
\hline
\end{tabular}

* 1 管路部のケープル温度 $105^{\circ} \mathrm{C}$ 時、オフセッ部のケープル温

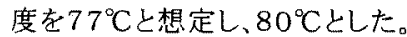

* 2 管路部のケープル温度 $105^{\circ} \mathrm{C}$ 時、MH内のケープル温度 が $95^{\circ} \mathrm{C}$ となる解析結果による。

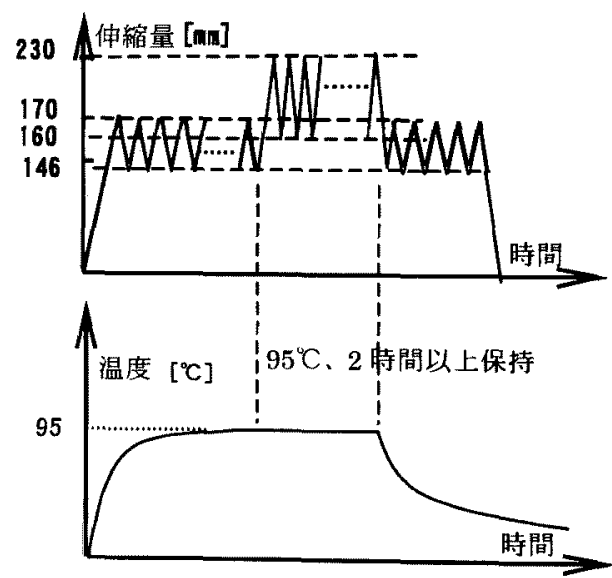

図6 熱伸縮パターン例(試料b-(2))

Fig. 6 Test pattern example of thermal expansion

2.3.3 考察 オフセット試験による金属遮蔽層の評価から、1 $05^{\circ} \mathrm{C}$ での温度条件でもワイヤー遮蔽層はその機能を損なう ような現象は認められなかったが、銅テープ遮蔽仕様では、 経年 19 年撤去品試料を用いたオフセット試験結果では、30 年相当以前から銅テープにシワが発生し、伸樎回数が增すと テープが破断に至ることが確認された。これらの結果から、銅 テープ遮蔽使用ケーブルはオフセット部ケーブルの曲げ歪 みが大きくなる尊体温度 $105^{\circ} \mathrm{C}$ 以上では使用困難と推察さ れる。 
<2.4>ケーブル拘束部の熱機械特性 一般に、ケーブル の拘束にはヒートサイクルにより荷重変動を生じる直線拘束 部・スネーク布設部の拘束等布設形状を維持するための拘 束と比較的荷重変動の小さい傾斜地や高低差がある箅所で のケーブル滑落防止のための拘束がある。

直線拘束部・スネーク部のクリート拘束部についてはオフ セット試験と同時に実施し、試験中の変形調查や試験後の ケーブル解体調查でまったく問題ないことを確認した。滑落 防止用のクリート拘束部については、ヒートサイクルによる影 響を調べるため拘束力試験を行った。

\subsection{1 クリート拘束力試煥}

（1）試臨方法 クリート拘束力試験では、垂直布設したケ一 ブルを1個のクリートで支持し、ケーブル自重と重りによりクリ 一トの設計拘束力荷重 $(66 \mathrm{kV}$ ケーブル、導体断面積 80 〜 $400 \mathrm{~mm}^{2}: 60 \mathrm{kgf} 、 600 \sim 800 \mathrm{~mm}^{2}: 100 \mathrm{kgf} 、 1000 \sim 20$ $\left.00 \mathrm{~mm}^{2}: 130 \mathrm{kgf}\right)$ 与え、常温 $105^{\circ} \mathrm{Cヒ一トサイクル}$

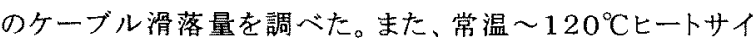
クルも実施した。供試ターブルはトリプレックスおよび単芯ク ーブルを用いた。試験方法を図7に示す。

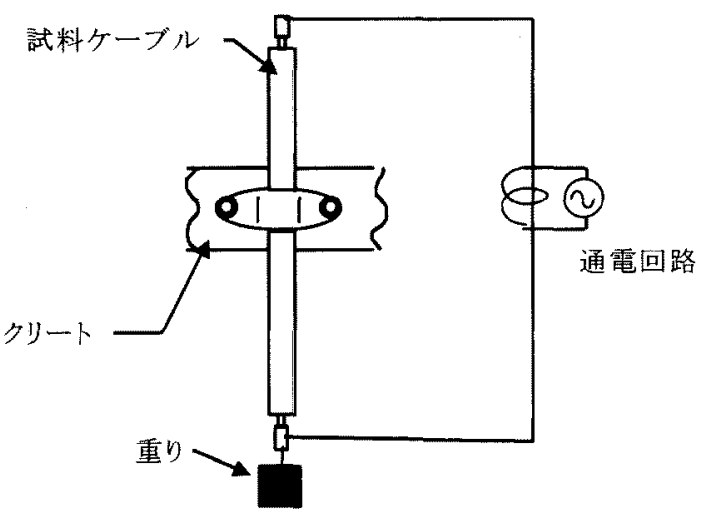

図7 クリート拘束力試験

Fig.7 Configuration of restraint force of cleats

(2) 試験結果 クリート拘束力試験にてケーブルの滑落を 測定した結果、個々の試験試料により滑落の状況が異なっ たものとなった。また滑落量についてもわずかな滑落量で飽 和するケースや、滑落量が大きく拘束力を増した方がよいと いら評価が得られたケースもあった。そのため滑落量につい ての共通した傾向は見つけられなかった。

2.4.2 拘束力增加策 滑落の状況を調查した結果、ゴムス ペーサーの熱によるへたりによりケーブルが移動していた。 このため、改良型スペーサとして耐熱型のゴムスペーサを試 作しクリート拘束力試験によりその性能を確認した。従来タイ プのスペーサを使用してもっとも大きな滑落を示したケーブ ルについての試験結果の比較を図8に示寸。改良型スペー サでは十分滑落を防止する効果があることが確かめられた。
<2.5> 高沮短地絡特性 CVケーブル高温運転時に短絡 事故や地絡事故が発生した場合のケーブルおよび接続部 の健全性を評価した。

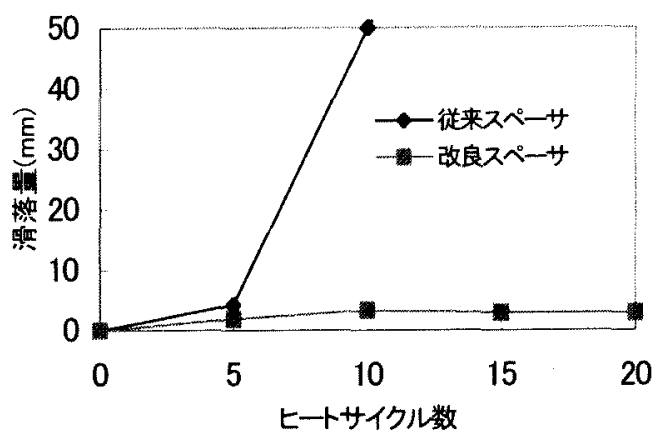

図8クリ一ト拘束力試験比較結果

Fig.8 The comparison of test results

2.5.1 試験方法 実線路が $105^{\circ} \mathrm{C} て ゙$ 運転されている状態 で、短䅂事故や地絡事故が発生した場合に線路が受け る影響を把握するため、試験線路での2 線短絡事故、な らびに1線地絡事故を模擬した通電試験を行った。

\section{(1) 2 線短絡試臨}

・供試試料: $66 \mathrm{kV} 3 \times 250 \mathrm{~mm}^{2}$ CVTケーブル

・試驗温度: $105^{\circ} \mathrm{C}($ ケーブル導体温度 $)$

・短絡条件: $31.5 \mathrm{kA} \times 1 \mathrm{sec}(2$ 相の導体に直列通電)

- 検証対象：管路口防水装置部、クリ一ト部、直載受金 物部

・調查項目: X線撮影(試験前後)、短絡試験後の耐電圧 試験 (AC・Imp。初期要求性能レベル)、解体 調查

・判定条件: ( X 線撮影) 短地絡電流通電前後でケーブル ワイヤー遮蔽層に構造的変化(大幅な片寄り や変形など)が発生していないこと

(解体調查)構造的異常がないことおよび絶 縁体寸法(厚さ・外径) が試験前後とも規格值 を満たすこと

（2） 1 線地絡試酸

・供試試料：66kV $1 \times 1200 \mathrm{~mm}^{2} \mathrm{CV}$ ケーブルトテープ 巻絶秝形普通接続部（以下TJとする）

・試験温度: $105^{\circ} \mathrm{C}$ (接続部スリーブ温度)

- 地䅂条件: $3 \mathrm{kA} \times 2 \mathrm{sec}$ (導体加遮蔽層一 2 相直列通 電)

・検証対象：テープ巻き式接続部、管路口防水装置部、 クリート部、直载受金物部

・調查項目: X線撮影(試験前後)、地絡試験後の耐電圧 試験(初期要求性能レベル)、解体調查

・判定条件: ( $\mathrm{X}$ 線撮影) 短地絡電流通電前後でケーブル ワイヤ一遮へい層や接続部鉛テープ遮へい 層に構造的変化(変形やシワ、切れなど)が 
発生していないこと

(解体調查) 構造的異常がないことおよび絶 粶体寸法(厚さ・外径)が試験前後とも規格值 を満たすこと

\subsection{2 試験結果}

（1）2線短絡試臨短絡電流を試料に通電した瞬間、 電磁力によって然り合わせた各相の間隔が大きく広がり、 試験終了後も完全には元に戻らなかった。

クリート部、管路口防水装置部、直載受金物部を対象に X線撮影を実施した。試験前後でワイヤーシールド形状 等内部棈造に変化は認められなかった。

試料を工場に持ち㷌り、1 $\mathrm{mp} .: \pm 485 \mathrm{kV} \cdot 3$ 回 $\rightarrow \mathrm{AC}$ : $130 \mathrm{kV} \cdot 1 \mathrm{~h}$ (常温)の耐電圧試験を実施した結果は良好で あり、ケーブルの初期要求性能レベル(1)に耐えることを 確認した。

耐電圧試験終了後、X線撮影を行ったクリート部、管路 口防水装置部、直載受金物部を対象に解体調查を行っ た。ケーブル内部構造に異常はなく、表6に示すように絶 縁体の厚さと外径については短絡試験履歴の無いサン プルとの有意差も認められなかった。

表62 線短絡試験後のケーブル絶䋑体寸法データ

Table6 Dimension of insulation after testing

\begin{tabular}{|c|c|c|c|c|}
\hline & \multicolumn{2}{|c|}{ 絶縁体外径 $(\mathrm{mm})$} & \multicolumn{2}{c|}{ 絶縁体厚さ $(\mathrm{mm})$} \\
\hline & 平均值 & 最小值 & 平均値 & 最小値 \\
\hline 供試試 & $39.30 \sim$ & $39.2 \sim$ & $9.28 \sim$ & $9.1 \sim$ \\
料 $(\mathrm{n}=6)$ & 39.50 & 39.4 & 9.42 & 9.3 \\
\hline オリジナ & $39.36 \sim$ & \multirow{2}{*}{39.2} & $9.32 \sim$ & $9.1 \sim$ \\
ル $(\mathrm{n}=2)$ & 39.42 & & 9.34 & 9.2 \\
\hline \multirow{2}{*}{ 規格值 } & $38.0 \sim$ & & 8.1 & 7.65 \\
& 41.0 & & 以上 & 以上 \\
\hline
\end{tabular}

（2） 1 線地絡試験 地絡電流を通電した結果、通電時 における試料の举動は認められなかった。クリート部、管 路口防水装置部、直載受金物部および中間接続部を対 象にX線写真撮影を実施した結果、試験前後での変化 は認められなかった。

地絡試験終了後、試料を工場に持ち㷌り、I $\mathrm{mp}: \pm$ $485 \mathrm{kV} \cdot 3$ 回 (常温) $\rightarrow \mathrm{AC}: 155 \mathrm{kV} \cdot 1 \mathrm{~h}$ の TJ初期要求レべ ル(1)耐電圧試験を実施し、結果は良好であった。

耐電圧試験終了後、X線撮影を行ったクリート部、管路 口防水装置部、直載受金物部およびTJを対象に解体调 査を行った。その結果、ケーブル、接続部とも内部構造 に異常はなく、絶縁体の厚さと外径についても表 7 に示 すように地絡試験履歴の無いサンプルとの有意差は認め られなかった。

2.5.3 まとめ実線路で $105^{\circ} \mathrm{C} の$ 高温運転状態にある線 路に短絡事故や地絡事故が発生した場合を模擬した通 電試験を行った。試験後の試料に対して耐電圧試験お よび解体調查を実施した結果、特に異常が認められない ことを確認した。
表 71 線地絡試娩後のケーブル絶縁体寸法データ

Table7 Dimension of insulation after testing

\begin{tabular}{|c|c|c|c|c|}
\hline & \multicolumn{2}{|c|}{ 絶縁体外径 $(\mathrm{mm})$} & \multicolumn{2}{|c|}{ 絶縁体厚さ $(\mathrm{mm})$} \\
\hline & 平均値 & 最小値 & 平均值 & 最小值 \\
\hline 供試試 & $64.86 \sim$ & $64.3 \sim$ & $9.96 \sim$ & $9.6 \sim$ \\
料 $(\mathrm{n}=4)$ & 65.02 & 64.6 & 10.02 & 9.7 \\
\hline オリジ & $64.84 \sim$ & $64.4 \sim$ & $10.02 \sim$ & $9.6 \sim$ \\
ル $(\mathrm{n}=2)$ & 64.88 & 64.6 & 10.10 & 9.7 \\
\hline \multirow{2}{*}{ 規格值 } & $64.2 \sim$ & & 9.0 & 8.5 \\
& 67.7 & & 以上 & 以上 \\
\hline
\end{tabular}

\section{3. 接続部金属遮蔽層の熱機械特性}

T了構成材料の1つとして金属遮蔽層がある。ケーブルの 高温使用により図9に示すようにコアの膨張量が増すことか

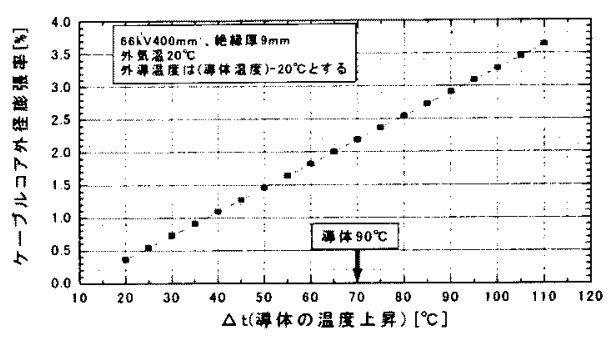

図9 ケーブルコアの膨張率試算例

Fig.9 Rate of expansion for cable core

ら、この金属遮蔽層に用いている鉛テープの寿命(疲労)特 性をテープ単体試験および赛機試験により評価した。

\section{<3.1> テープ単体試験}

3.1 .1 試験力法 通常用いられている鉛遮蔽テープ(純鉛、 幅 $25 \mathrm{~mm}$ 、厚さ0. $1 \mathrm{~mm}$ )の片端を固定し、試料が破断する まで他の片端に周期的な変位を連続して与えた。変位は、 ケーブル導体温度高温時のコア膨張量を考慮し、伸張率と して $1 ， 2 ， 3 \%$ (導体温度 $55 \sim 110^{\circ} \mathrm{C}$ 相当)の範囲とし、試験 は常温で行った。試験方法を図10に示す。
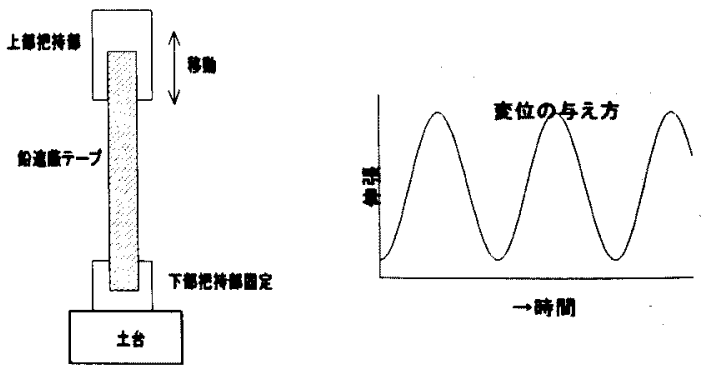

図 10 試筷方法

Fig.10 Method of Testing

3.1.2 試結果及び考察 破断までの回数を図 11 に示す。 一般に金属の疲労特性として振動の周波数が高くなると破 壊までの回数が增大し、周波数と破断回数を両対数で整理 すると直線になることが知られている。 


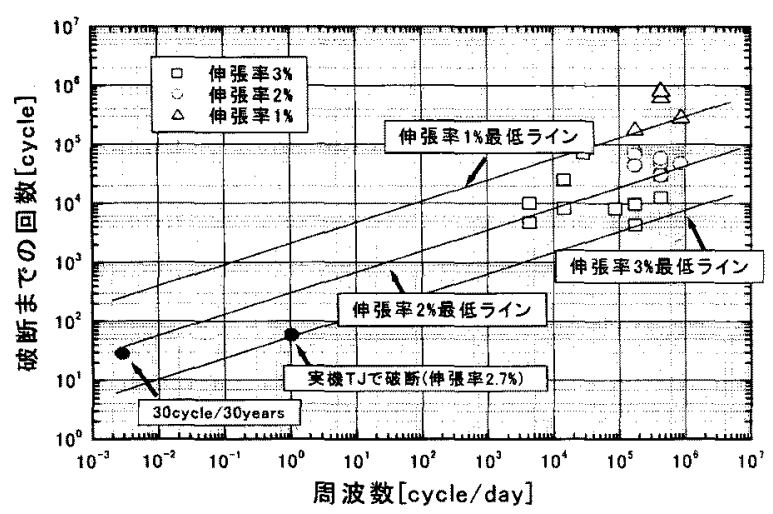

図11 鉛デープの破断特性

Fig.11 Characteristics of $\mathrm{Pb}$ tape break

図11中の直線は後述する実機TJの試験結果をもとに引い たものである。また、鉛の疲労には温度特性があり、温度が $30^{\circ} \mathrm{C}$ 上昇すると寿命が半減するとの報告もある(1)。えらを あわせて考え、伸張率 $1 \%$ から伸張率 $3 \%$ は同じ傾きを持つ と考えると、設計(鉛テープが破断しないこと)寿命 30 年を想 定した場合、現在の使用温度である $90^{\circ} \mathrm{C}$ (図9よりケーブル 導体 $90^{\circ} \mathrm{C}$ とき伸張率は2.2\%になる)が妥当であり、さら に温度を上げると鉛テープが破断する危険性があると判断 できる。

\section{<3.2> TJ実機試験}

3.2.1 試験方法 図12に示すTJで図13に示す線路を構築

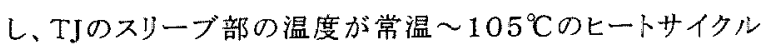
(8時間ON、16時間 $O F F)$ となるよう通電した。ヒートサイク ルの影響を確認するためヒートサイクル30回終了毎にX線 撮影を行い、最終的にヒートサイクル 224 回終了後、解体調 查を行った。

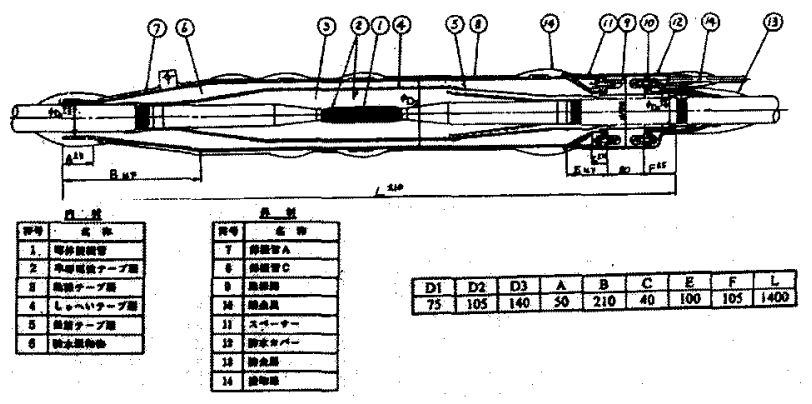

図 12 TJ構造図

Fig.12 Structure of TJ

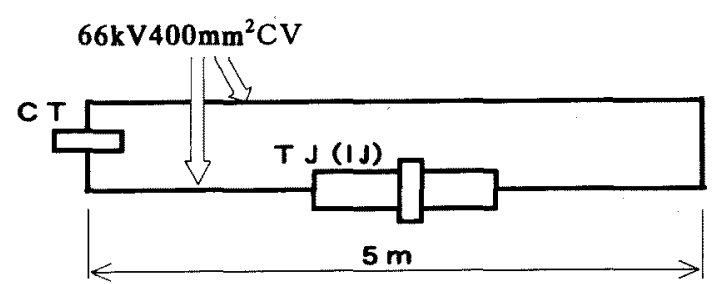

図13試糇線路

Fig.13 Test Layout

\subsection{2 試酸結果及び考察}

60 サイクル経過時点で、鉛遮蔽テープのクラックが確認 できた。また、224サイクル経過後の解体調查により、鉛テ 一プにクラックが入り電気的に浮遊している部分があること が確認できた。その他の部位、たとえば、補強絶縁テープや コンパウンドに異常な点は見られなかった。

鉛遮蔽テープに電気的に浮遊している部分が存在すると 高周波のサージが侵入した場合、浮遊している鉛遮蔽テー プ間で放電が発生し、主絶縁部分に影響をおよぼすおそれ がある。従って、TJの高温使用に関して恃金属遮蔽層に留 意する必要がある。実機試験、テープ単体試験の結果から 金属遮蔽層を鉛テープのみで行う構造のTJにおいて、10 $5{ }^{\circ} \mathrm{C}$ での使用は今回の結果からは困難であると判断できる。

\section{4.まとめ}

$66 \mathrm{kV}$ 級CVケーブル及びテープ巻き絶縁形接続部に対し て、導体温度 $105^{\circ} \mathrm{C}$ 相当以上の条件に扔ける熱機械特性 を総合的に検証した。結果を以下に要約する。

$\cdot 140^{\circ} \mathrm{C}$ 以上の使用ではクリート把持部などでケーブルの変 形が極端に大きくなる。

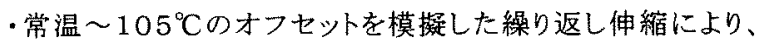
ケーブル遮水層の遮水性能が大きく低下し、銅テープ遮 蔽層が破断した。銅ワイヤー遮蔽層は問題が生じなかっ た。

・常温 $105^{\circ} \mathrm{C}$ 、常温〜 $120^{\circ} \mathrm{C}$ のートサイクルによりクリー ト拘束力が低下し、ケーブルのずり落ちが観測されることが あった。

・105ํでの短地絡によりケーブル、接続部に損傷を生じる ことはなかった。

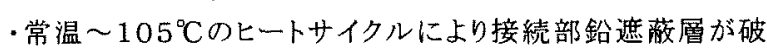
断する場合があることが分かった。

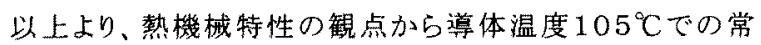
時運転は困難と考えられる。

(平成 12 年 3 月 24 日受付, 平成 12 年 8 月 23 日再受付)

\section{参考文献}

(1)電気協同研究第 40 巻第 1 号「特高ケーブルの導体許容 温度」

(2)中出他: 平成 11 年電気学会B部門大会No. 367 


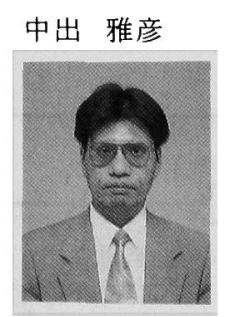

松井俊哉

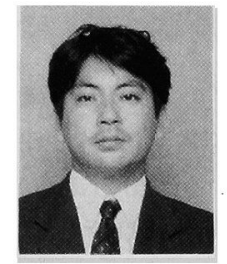

\section{(正員) 1966 年 9 月 2 日生。1990年東} 京都立科学技術大学工学部電子シ ステム工学科卒業。同年東京電力 (株) 入社。現在銀座支店流通設備 部所属。主として地中電力ケーブル の研究開発に従事。

田中 秀郎

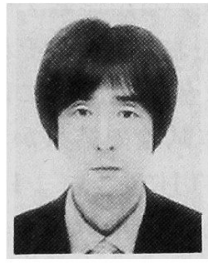

西川哲

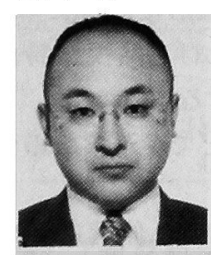

片貝 昭史

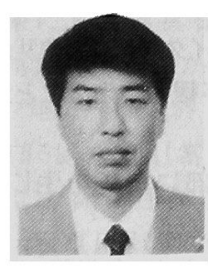

(正員) 1957年11月4日生。1983年 早稲田大学大学院理工学研究科電 気工学専攻博士前期課程修了。同年 日立電線 (株) 入社。現在同総合技 術研究所第1部所属。主として架橋ポ リエチレン電カケーブルならびに絶 縁材料の研究開発に従事。

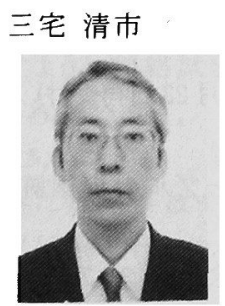

正員) 1955 年 8 月 25 日生。1981年宮 崎大学大学院工学研究科応用物理 学専攻修了。同年昭和電線電纜 (株) 入社。現在同技術開発センタ 一・電力システム開発室所属。主とし て電力ケーブルの技術開発に従事。
京大学大学院工学系研究科電気工 専攻修士課程修了。同年 4 月古河 研究所勤務。電力ケーブル関連技術 及び劣化診断技術の研究開発に従 事。

(正員) 1966 年 12 月 23 日生。1990年 京都大学工学部電気工学科卒業。同 力・産業電線事業部技術部所属。主 として地中電カケーブルの設計、開 発に従事。

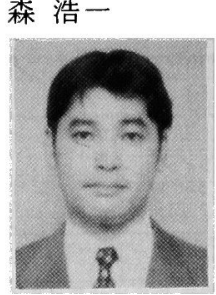

(正員) 1967 年 1 月 27 日生。1992年京 都大学工学部電気系学科卒。同年三 菱電線工業 (株) 入社。現在同電力シ ステム課所属。主として地中電力ケー ブルシステムの設計業務に従事。 